\title{
PENGAMBILAN KEPUTUSAN PRO LIFE PADA REMAJA DENGAN KEHAMILAN TIDAK DINGINKAN (KD)
}

TASYA NIA NUDDIN HALAWA

tasyahalawa1705@gmail.com

\section{Latar Belakang}

Masa remaja adalah masa transisi antara masa kanak-kanak dengan dewasa dan relatif belum mencapai tahap kematangan mental dan sosial. Remaja bisa saja mengatakan bahwa seks bebas atau seks pranikah itu aman untuk dilakukan. Namun, bila remaja melihat dan memahami akibat dari perilaku itu,ternyata lebih banyak membawa kerugian. Salah satu resikonya adalah kehamilan di luar nikah. Kehamilan diluar nikah saat ini dikarenakan adanya dorongan seksual pada remaja yang tidak terkontrol membuat remaja berani untuk melakukan kegiatan seks pranikah yang dapat menjadi sumber mala petaka yang dapat menghancurkan masa depan dan cita cita mereka. Seperti keha,ilan diluar nikah yang saat ini marak terjadi di kalangan remaja .Harga diri dan komitmen hubungan pada relasi diadik, serta sikap positif ditengarai menjadi penyebab munculnya perilaku seks pranikah Seks bebas merupakan hubungan yang dilakukan oleh laki-laki dan perempuan tanpa ikatan perkawinan Pacaran remaja meningkat sejalan dengan meningkatnya kejadian pemaksaan perilaku seksual pranikah dalam pacaran, kehamilan diluar nikah dan aborsi. Menurut KemenPPPA (2017), penanganan dan pencegahan terhadap pemaksaan perilaku seksual selama pacaran dapat dilakukan dengan bersikap asertif terkait seksual. Oleh karena itu, perlu dilakukan pencegahan melalui peningkatan asertivitas seksual pada remaja putri Tujuan penelitian : Untuk mengetahui bagaimana pengambilan keputusan pro life pada remaja dengan KTD. Pengambilan keputusan untuk melanjutkan kehamilan yang dialami merupakan keputusan yang dibuat oleh orang tua dengan cara menikahkan anak remajanya. Alasan informan mengikuti keputusan yang dibuat oleh orang tua untuk melanjutkan kehamilan yaitu mereka patuh dengan apa yang dikatakan orang tua, takut tambah mengecewakan orang tua. Sebagian besar proses pengambilan keputusan 
untuk melanjutkan kehamilan dengan kasus KTD tidak melalui konseling dengan tenaga kesehatan atau konselor tetapi orang tua mengambil dari pengalaman riil disekitar yaitu jika ada anak remaja perempuan hamil diluar nikah maka harus segera dinikahkan.

Kata kunci. Remaja, KTD, Pengambilan Keputusan Pro Life, Perilaku seks pranikah

\section{Metode}

Penelitian ini menggunakan pendekatan kualitatif dengan desain studi kasus untuk mengumpulkan informasi secara mendalam tentang bagaimana pengalaman dan perilaku remaja dengan KTD. proses pacaran, keluarga, lingkungan masyarakat adalah cara yang efektif dan tradisional bagi orang untuk berbagi dan mengaskan ide, isu, dan nilai-nilai dari apa yang dialami oleh mereka Kemudian, dilakukan evaluasi singkat dimana penyuluh mengajukan 3 pertanyaan kepada peserta. Adapun rincian materi perilaku seksual seperti definisi, tahapan perilaku seksual dalam pacaran, dan Hasil

Dari hasil penyuluhan yang telah dilakukan, sebelum diberikan pemberian materi mengenai perilaku seksual, sebagian besar peserta belum mengetahui tentang perilaku seksual dampak dari perilaku seksual pranikah.

Kemudian, materi asertivitas seksual yaitu terkait bagaimana menerapkan asertivitas seksual. Pertama, menghormati hak-hak orang lain dan diri sendiri terkait seksual, seperti tidak takut mengutarakan pendapat kepada pacar terkait batasan aktivitas seksual dalam pacaran walaupun usia pacar jauh lebih tua dan tidak takut menolak ajakan pacar dalam melakukan aktivitas seksual. Kedua, berani mengemukakan pendapat secara langsung terkait seksual, seperti menyampaikan pendapat dan penjelasan secara tegas kepadsa pacar dalam aktivitas seksual.

dan bentuk-bentuk perilaku seksual. Sebagian besar dari mereka berpendapat bahwa perilaku seksual diwujudkan dalam bentuk sexual intercourse saja. Mayoritas remaja mengetahui bahwa kehamilan merupakan salah satu dampaknya, 
namun mereka tidak mengetahui dampak dari tiap perilakunya. Berdasarkan kareteristiknya remaja yang mengalami KTD adalah remaja dalam tahap pertengahan (14 sampai 17 tahun).

Masa ini dimana perkembangan fisik mereka bagitu menonjol. Remaja akan cemas dengan perkembangan fisiknya, sekaligus bangga bahwa hal itu menunjukkan bahwa ia memang bukan anak-anak lagi.. pada masa ini emosi remaja menjadi sangat labil akibat dari perkembangan hormon-hormon seksualnya yang begitu pesat. Keinginan seksualnya juga semakin kuat. Pada remaja wanita ditandai dengan datangnya menstruasi pertama sedangkan pada remaja laki-laki ditandai dengan mimpi basah yang pertama. Remaja menjadi bingung dan malu akan hal ini, sehingga orang tua harus mendampingi serta memberikan pengertian yang baik dan benar mengenai seksualitas. Harga diri tidak memiliki korelasi yang signifikan dengan semua variabel yang ada, kecuali dengan komitmen hubungan.

Sementara itu, hal lain yang tampak berkorelasi secara signifikan dengan perilaku seks pranikah adalah komitmen hubungan, serta sikap terhadap perilaku seks pranikah, baik permissiveness with dan without affection. Komitmen hubungan memiliki korelasi dengan perilaku seks pranikah dan usia. Artinya semakin kuat komitmen hubungan maka akan semakin permisif seks pranikah dilakukan, dan semakin tua usia partisipan maka akan semakin kuat komitmen hubungan dibangun.

Usia tidak berkorelasi dengan hampir semua variabel yang ada kecuali komitmen hubungan. Hasil lainnya juga memperlihatkan bahwa semakin positif sikap individu bahwa hubungan seks boleh dilakukan atas dasar cinta, atau tanpa cinta, maka akan semakin permisif perilaku seks pranikah dilakukan. Paparan yang lebih jelas tampak Setelah pemberian materi mengenai perilaku seks dan dampaknya, pemateri memberikan materi mengenai pencegahan perilaku seksual yang dapat dilakukan oleh remaja secara sederhana yaitu dengan memberikan pengetahuan terkait asertivitas seksual.

Penyuluh terlebih dahulu menanyakan bagaimana jika peserta 
mendapat ajakan melakukan perilaku seksual pranikah oleh pacar namun sebagian besar dari mereka menunjukkan sikap yang cenderung agresif dan adapula yang bersikap raguragu atau submisif.

Berdasarkan hasil penelitian juga tampak bahwa hanya komitmen hubungan dan sikap terhadap perilaku seks pranikah yang memiliki pengaruh terhadap perilaku seks pranikah yang dilakukan remaja. Sementara itu, yang menarik adalah bahwa ternyata harga diri tidak memiliki pengaruh langsung terhadap perilaku seks pranikah, namun memiliki pengaruh langsung terhadap komitmen hubungan.Hasil penelitian juga memperlihatkan bahwa harga diri tidak berpengaruh terhadap sikap

\section{Pembahasan}

Perilaku seks pranikah merupakan permasalahan dan sekaligus fenomena sosial yang kian lazim dijumpai di dalam masyarakat. Pergeseran norma baik-buruk, benarsalah, terutama dalam konteks seksualitas semakin jelas terlihat. Pada kelompok remaja, perilaku seks pranikah semakin dianggap normatif dan tidak 1 Korespondensi mengenai partisipan akan perilaku seks pranikah.

Usia reproduksi sehat adalah usia 20-35 tahun dimana oragn reproduksi sudah berkembang dengan sempurna. Sedangkan hasil dari wawancara dengan informan didapatkan bahwa usia yang termuda saat melakukan hubungan seksual yaitu usia 14 tahun. Hubungan seksual pada usia kurang dari 20 tahun merupakan salah satu faktor resiko terjadinya kanker servik pada wanita yang dapat berakibat lebih buruk pada kesehatan reproduksi wanita sehingga perlu kiranya meningkatkan informasi perilaku seksual sehat bagi remaja sedini mungkin, supaya terhindar dari perilaku seksual yang dapat membahayakan kesehatan.

artikel ini dapat melalui menjadi hal yang tabu lagi seperti dahulu. Salah satu bentuk perilaku seks pranikah yang paling permisif adalah dilakukannya hubungan seks. Remaja yang hamil merupakan klien obstetrik yang beresiko tinggi. Remaja hamil juga sering mengekpresikan sikap yang tidak realistik yang dapat ditunjukkan di sekolah, tempat kerja, proses parenting 
dan proses sosialisasi.

Remaja yang mengalami kehamilan tidak diinginkan (KTD), mengalami beberapa perlakuan baik dari pihak laki-laki, keluarga maupun masyarakat secara umum.Remaja perempuan lebih banyak mendapatkan tekanan sosial daripada remaja laki-laki. Sikap sosial terhadap remaja laki-laki cenderung fleksibel dan hak pendidikan bagi remaja laki-laki dipertahankan daripada remaja perempuan. Remaja perempuan yang mengalami KTD memandang diri mereka keluar dari definisi ideal dan menyalahi struktur normatif keluarga dari sudut pandang sosial dan agama. Hal ini menyebabkan ketakutan, kebingungan, stress, rasa malu, rasa bersalah, dan bahkan depresi. Mereka akan lebih cenderung mencari layanan yang aman secara sosial daripada aman secara kesehatan fisik. Masa remaja disebut juga masa penghubung atau masa peralihan antara masa kanakkanak dengan masa dewasa.

remaja adalah yang berusia 1019 tahun. Pada masa remaja terjadi perubahanperubahan besar dan esensial mengenai fungsifungsi rokhaniah dan jasmani, terutama fungsi seksual. Terjadi kematangan fungsi jasmani maupun yang biologis. Pada masa ini, energi atau libido seksual yang awalnya laten di masa pra remaja menjadi hidup.

Perubahan tersebut mengakibatkan adanya dorongan untuk berperilaku seksual bertambah. Perilaku seksual merupakan segala tindakan yang didorong oleh hasrat seksual terhadap lawan jenis maupun dengan sesama jenis. Adapun bentuk perilaku seksual salah satunya yaitu pacaran. Pacaran sudah menjadi hal yang lumrah dilakukan oleh remaja pada saat ini. Adapun tahapan perilaku seksual pada masa pacaran dimulai dari berpegangan tangan, berpelukan, necking, meraba bagian tubuh yang sensitif, petting, oral seks, hingga sexual intercourse Perilaku seksual pranikah dapat menimbulkan dampak negatif setelahnya seperti Kehamilan Tidak Diinginkan (KTD) hingga aborsi. Pacaran dan perilaku seksual berkaitan erat satu sama lain. Berpacaran pada usia remaja, dikhawatirkan belum memiliki keterampilan hidup yang mumpuni sehingga kelompok remaja memiliki perilaku pacaran yang tidak sehat 
Komitmen hubungan juga dianggap memengaruhi perilaku seks pranikah individu. Komitmen hubungan dianggap penting dalam melandasi relasi diadik yang bersifat romantis antar dua individu, terutama pria dan wanita.

Komitmen hubungan pada dasarnya adalah niat individu untuk meneruskan hubungan yang dimilikinya bersama pasangan ke arah yang lebih serius. Sementara itu, komitmen biasanya terkait dengan tujuan tertentu. Di dalam riset ini, komitmen hubungan diusung sesuai dengan konsep positif yang diidentifikasi sebagai approach commitment yang mengedepankan usaha untuk menjaga dan meneruskan hubungan yang telah terbina. Secara lebih lanjut juga dijelaskan bahwa hubungan yang lebih serius merujuk pada perihal subjektif (orientasi jangka panjang, kelekatan psikologis dengan pasangan), dan karakteristik objektif (status formal hubungan, legalitas hubungan) yang menjadi perhatian dari individu terhadap pasangannya. Ketika individu memiliki komitmen yang besar dalam melanjutkan hubungan romantis dirinya dengan pasangan ke arah yang lebih serius, maka individu tersebut dapat melakukan pengorbanan dalam banyak hal, termasuk dalam hal seksualitas. Di dalam komitmen hubungan terdapat insentif dan ganjaran dan hal ini terkait dengan usaha mempertahankan hubungan di masa depan.

bahwa demi mempertahankan hubungan dan mendapatkan kepuasan dibutuhkan pengorbanan yang dilakukan individu dalam relasi diadik. Salah satu hal yang terkait dengan kepuasan pasangan adalah seksualitas, terutama dalam konteks relasi diadik. menemukan bahwa semakin tinggi komitmen hubungan maka akan semakin tidak permisif perilaku seks individu dengan orang lain selain pasangannya. Artinya, permisivitas seks dilakukan kepada pasangan tetap saja.

Individu beranggapan bahwa komitmen merupakan dasar kepercayaan yang sifatnya diadik, sehingga hubungan seks hanya pantas dilakukan terhadap pasangan tetap berlandaskan komitmen. menyebutkanbahwa komitmen berhubungan berpengaruh terhadap kepuasan akan relasi seks premarital dengan pasangan. 
Sementara itu temuan berbeda yang juga mendukung temuantemuan tersebut $\mathrm{di}$ atas adalah bahwa komitmen hubungan berkorelasi secara negatif dengan sikap terhadap perilaku seks yang dilakukan dengan individu yang bukan pasangan tetapnya.

Hal ini menjelaskan bahwa aktivitas seks dengan pasangan tetap dapat terjadi dengan berdasarkan komitmen hubungan yang dipersepsikan secara positif oleh individu terhadap pasangannya. pengetahuan remaja tentang seks masih sangat kurang. Faktor ini ditambah dengan informasi keliru yang diperoleh dari sumber yang salah, seperti mitos sep utar seks, VCD porno, situr porno di internet, dan lainnya akan membuat pemahaman dan persepsi anak tentang seks menjadi salah.

Pendidikan seks sebenarnya berarti pendidikan seksualitas yaitu suatu pendidikan seksual dalam arti luas yang meliputi berbagai aspek yang berkaitan dengan seks, diantaranya aspek biologis, orientasi, nilai sosiokultur dan moral serta perilaku. Pengetahuan informan yang pernah melakukan hubungan seks bebas tentang perilaku seks bebas yaitu perilaku seks yang dilakukan sebelum adanya ikatan pernikahan. Bahkan ada informan yang mengatakan bahwa perilaku seks bebas adalah pembuktian dari rasa saling memiliki dan rasa saling tulus mencintai dan itu hal yang dilarang agama. Selanjutnya pengetahuan informan yang belum pernah melakukan hubungan seks bebas tentang perilaku seks bebas yaitu perilaku seks yang dilakukan sebelum adanya ikatan pernikahan, kebebasan berekspresi, wujud dari ungkapan kasih sayang bahkan perilaku seks bebas dianggap menjadi suatu hal yang wajar dilakukan oleh mereka.

Hubungan sikap dengan niat pengambilan keputusan dalam menentukan jarak kehamilan selanjutnya Sebagian besar responden memiliki sikap yang positif dan memiliki niat yang tinggi dalam menentukan jarak kehamilan selanjutnya. Responden mengerti akan manfaat mengatur jarak kehamilan selanjutnya baik untuk ibu dan bayi, selain itu responden memiliki persepsi yang positif terhadap mengatur jarak kehamilan selanjutnya. Sikap yang positif akan menimbulkan niat yang 
tinggi dalam menentukan jarak kehamilan selanjutnya. Fakta tersebut didukung dengan hasil uji statistik yang menunjukkan bahwa ada hubungan yang signifikan antara sikap dengan niat pengambilan keputusan dalam menentukan jarak kehamilan selanjutnya.

Hubungan norma subjektif dengan niat pengambilan keputusan dalam menentukan jarak kehamilan selanjutnya Sebagian responden memiliki norma subjektif yang kuat, namun niat responden dalam menentukan jarak kehamilan tidak selalu tinggi.

Hal tersebut disebabkan responden hanya mendengarkan nasihat dan saran dari orang lain diantaranya orang tua, pasangan/ suami, rekan kerja, keyakinan, dan tetangga akan tetapi pengambil keputusan utama tetap pada diri sendiri. Responden percaya dan yakin akan kemampuannya untuk memutuskan jarak anak pertama dengan anak selanjutnya.

Hasil penelitian menunjukkan bahwa pengaruh norma subjektif kuat, namun tidak mempengaruhi niat dalam menentukan jarak kehamilan selanjutnya karena dalam penelitian responden sendiri yang mengambil keputusan dalam menentukan jarak kehamilan selanjutnya, nasihat orang lain menjadi informasi dan masukan responden.

Hasil yang didapat dari penelitian ini penting bagi petugas kesehatan untuk dapat memberikan informasi dan edukasi mengenai jarak kehamilan, termasuk sasaran atau target edukasi yang berperan dalam pengambilan keputusan pada ibu primipara yang harus dicapai oleh tenaga kesehatan diantaranya orang tua, pasangan/ suami, rekan kerja, keyakinan, dan lingkungan sosial.

Remaja yang menyalurkan dorongan seksualnya menjadi perilaku seksual seperti di atas, nantinya akan menimbulkan konflik pada dirinya yang akan berdampak pada psikologis, fisiologis, sosial, maupun fisiknya. dampak yang akan ditimbulkan dari perilaku seksual pranikah diantaranya; perasaan marah, takut, cemas, depresi, rendah diri, merasa bersalah, berdosa, kehamilan yang tidak diinginkan sehingga melakukan aborsi, putus 
sekolah, dikucilkan, serta terkena PMS (Penyakit Menular Seksual).

Meskipun demikian remaja cenderung untuk tetap berdalih sebagai pembenaran diri bahwa perilaku yang dilakukan, dalam hal ini perilaku seksual pranikah sudah biasa terjadi dan semua orang melakukan hal tersebut. Jadi perilaku yang dilakukan bukanlah suatu aib yang harus dihindari. Dorongan seksual yang dirasakan seseorang dapat memicu timbulnya perilaku seksual. Perilaku seksual yang dilakukan remaja bertentangan dengan norma yang berlaku di masyarakat.

Perilaku seksual tersebut merupakan bukti adanya perilaku sosial dalam bidang hubungan heteroseksual yang seharusnya dapat dikembangkan dengan lebih positif mengikuti norma dan aturan yang berlaku Jadi seharusnya remaja melakukan tugastugas perkembangannya dengan baik sehingga mampu menunjukkan prestasi belajarnyadan tidak melakukan hal-hal yang negatif, salah satunya seperti perilaku seksual pranikah Beberapa faktor-faktor perilaku seksual pranikah pada remaja adalah pengaruh biologis, pengaruh orang tua, pengaruh teman sebaya, akademik, pemahaman kehidupan sosial, pengalaman seksual, pengalaman dan penghayatan nilai-nilai agama, factor kepribadian, dan pengetahuan mengenai kesehatan reproduksi.

Dari faktor- factor yang disebutkan di atas, penulis menitik beratkan pembahasan pada faktor teman sebaya, kemudian dari faktor tersebut dilihat sejauh mana konformitas terhadap teman sebaya dapat mempengaruhi perilaku seksual pranikah pada remaja. Adapun alas an pemilihan faktor tersebut adalah perilaku seksual pranikah pada remaja biasanya diawali dengan rasa ingin tahu untuk menambah pengalaman serta penasaran ingin mencoba karena pengalaman temannya yang sudah terlebih dahulu melakukan hubungan seksual pranikah, sehingga akhirnya perilaku tersebut menjadi hal yang biasa untuk dilakukan.

konformitas dapat terjadi karena remaja lebih banyak berada di luar rumah bersama dengan teman-teman sebaya sebagai kelompok, maka dapatlah dimengerti bahwa pengaruh teman-teman sebaya pada sikap, 
pembicaraan, minat, penampilan,dan perilaku lebih besar daripada pengaruh keluarga.

Bagi remaja pandangan terhadap dirinya merupakan hal yang paling penting Pada masa remaja, remaja cenderung menyesuaikan dengan teman teman sebayanya, konformitas terjadi apabila individu mengadopsi sikap atau perilaku orang lain karena merasa didesak oleh orang lain (baik desakan nyata atau hanya bayangan saja). Desakan untuk berperilaku sama pada kawan-kawan sebaya cenderung sangat kuat selama masa remaja, hal tersebut dilakukan karena dorongan untuk diterima dalam kelompok tinggi. Rasa kebersamaan, persaudaraan, dan sikap konformitas remaja sangat tinggi dan mereka bisa keliru menggunakan perasaan tersebut untuk melakukan hal-

\section{Penutup}

Komitmen hubungan memiliki pengaruh terhadap dilakukannya perilaku seks pranikah, walaupun tidak sebesar pengaruh yang diberikan sikap terhadap perilaku seks pranikah. Sikap positif terhadap perilaku seks pranikah hal yang sifatnya negatif. Hal-hal yang bersifat negatif dalam hal ini, contohnya seperti perilaku merokok, membolos, minum-minuman keras, bahkan perilaku seksual pranikah. Bila remaja masuk ke dalam kelompok yang teman temannya sudah aktif melakukan perilaku seksual pranikah, maka tidak menutup kemungkinan remaja tersebut juga akan melakukan perilaku seksual pranikah karena remaja cenderung bersifat konformis.

Definisi konformitas itu sendiri merupakan suatu jenis pengaruh sosial ketika seseorang mengubah sikap dan tingkah laku mereka agar sesuai norma sosial yang ada membagi aspek konformitas menjadi lima,yaitu; peniruan, penyesuaian, kepercayaan, kesepakatan, ketaat.

tetap menjadi salah satu faktor pendorong utama dilakukannya perilaku seks pranikah. Temuan ini kian menegaskan banyak temuan studi-studi sebelumnya. Sementara itu, tidak adanya pengaruh harga diri 
memperlihatkan bahwa variabel ini bersifat sangat dinamis dalam studistudi terkait perilaku seks dan tetap berharga untuk dilibatkan dalam studistudi perilaku seks berikutnya dengan konteks permasalahan atau partisipan yang berbeda.

Karateristik utama dalam penelitian ini adalah remaja yang mengalami KTD yang melanjutkan kehamilan. Usia informan utama antara 14-17tahun. Empat informan berusia dibawah atau sama dengan 15 tahun, dan tiga informan berusia diatas 15 tahun. Semua informan utama masih Saran

Ada beberapa saran yang dapat dikemukakan terkait hasil studi ini. Pertama, mempertimbangkan peran variabel sosial budaya seperti standar ganda seksual, atau variabel yang terkait dengan proses perkembangan individu seperti sejarah perilaku seks individu. Kedua, memperluas cakupan demografis partisipan ke kota-kota kecil yang memiliki kemajuan pembangunan

\section{Daftar Pustaka}

berstatus sebagai pelajar 2 . Konsekuensi yang ditimbukan antara lain konsekuensi pendidikan, psikologis, dan sosial. Pada konsekuensi pendidikan semua informan dikeluarkan dari sekolah. Dari 4 informan yang berusia dibawah 15 tahun hanya 1 informan yang ingin melanjutkan sekolah kejenjang yang lebih tinggi dan 1 Informan yang berusia 15-17 tahun yang ingin melanjutkan sekolah ke perguruan tinggi. Konsekuensi psikologis dan sosial adalah stress, perasaan malu dengan masyarakat sekitar.

tidak sepesat di kota-kota besar. Ketiga, memberdayakan teman sebaya sebagai agen perubahan sosial terutama dalam hal sosialisasi konsekuensi negatif perilaku seks pranikah. Hal ini mungkin saja lebih efektif dalam menumbuhkan sikap negatif terhadap perilaku seks pranikah melalui kelompok yang memang memiliki kelekatan erat pada individu di masa remaja akhir. 
1. Simamora, R. H. (2019). Menjadi perawat yang: CIH'HUY.

Surakarta : Kekata Publisher.

2. Simamora, R. H.

(2005). Hubungan Persepsi

Perawat Pelaksana Terhadap

Penerapan Fungsi

Pengorganisasian Yang

Dilakukan Oleh Kepala Ruangan

Dengan Kinerjanya Diruang Rawat

Inap RSUD Koja Jakarta

Utara (Doctoral dissertation,

Tesis FIK UI, Tidak

dipublikasikan).

3. Dewi Sartika Rahadi, Sofwan Indarjo (2017). PERILAKU SEKS BEBAS PADA ANGGTA CLUB MOTOR $X$ KOTA SEMARANG TAHUN 2017. Jurnal of Health Education, 2 (2).

4. Wahyu Rahardjo1, Ajeng Furida Citra, Maizar Saputra3, Meta Damariyanti, Aprillia Maharani Ayuningsih \& Marcia Martha Siahay (2017). Perilaku Seks Pranikah pada Mahasiswa: Menilik Peran Harga Diri, Komitmen Hubungan, dan Sikap terhadap Perilaku Seks Pranikah, Jurnal Psikologi 44(2).

5. Visi Aurora Amartha, Iffa Fathimiyah, Laili Rahayuwati, Imas Rafiyah (2018). Pendidikan Kesehatan Mengenai Pencegahan Perilaku Seksual melalui Peningkatan Asertivitas pada Remaja Putri. Jurnal MKK, 1 (1)

6. Nur Alfiyah1, Tetti Solehati, Titin Sutini (2018). Gambaran Faktor faktor yang Berhubungan dengan Perilaku Seksual Pranikah pada Remaja di SMPN 1 Solokanjeruk Kabupaten Bandung. JPKI 4(2).

7. Kadar Kuswandi, Ismiyati, Darti Rumiatun (2019). ANALISIS KUALITATIF PERILAKU SEKS BEBAS PADA REMAJA DI KABUPATEN LEBAK QUALITATIVE ANALYSIS OF FREE SEX BEHAVIOR IN ADOLESCENTS

IN LEBAK REGENCY. Jurnal Kesehatan Poltekkes Palembang, 14(1). 
8. Ayu Rahmaditha Apsari1, Santi Esterlita Purnamasari (2017). HUBUNGAN ANTARA KONFORMITAS DENGAN PERILAKU SEKSUAL PRANIKAH PADA REMAJA. Journal InSight, 19(1).

9. Anissa Nurhayati, Nur Alam Fajar, Yeni (2017). DETERMINAN PERILAKU SEKSUAL PRANIKAH PADA REMAJA SMA NEGERI 1 INDRALAYA UTARA. Jurnal IImu Kesehatan Masyarakat, 8(2):8390.

10. Natalia Haris Krisprimada, Tiyas Kusumaningrum, Aria Aulia Nastiti (2019). Analisis faktor niat pengambilan keputusan dalam menentukan jarak kehamilan pada ibu primipara diPuskesmas Mulyorejo Surabaya. Jurnal Keperawatan dan Pemikiran Ilmiah, 5(3).23-31.
11. Lia Mulyanti

(2014).

PENGAMBILAN

KEPUTUSAN

PRO LIFE PADA REMAJA DENGAN KEHAMILAN TIDAK DIINGINKAN

DI

SEMARANG. Jurnal keperawatan, 3(3).

12. Fariza

Fathin

(2015).

Pengambilan Keputusan pada Remaja yang Mengalami Kehamilan di Luar Nikah (Studi di Kabupaten Mojokerto Jawa Timur). JURNAL SOSIAL DAN POLITIK, 5(2). 